\title{
POTENTIAL USE OF NATURAL MADIMAK PLANT AS AN HERBAL TEA? A RESEARCH IN THE PROVINCE OF DUZCE ${ }^{12}$
}

\author{
Tüketicilerin Doğal Madımak Bitkisini Çay Olarak Kullanabilirler mi? Düzce İlinde Bir Araştırma
}

Assoc. Prof. Dr. Muammer MESCI*

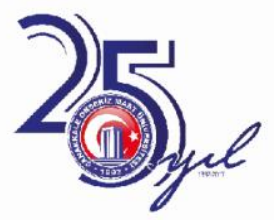

Yayın Bilgileri

Kabul tarihi: 11.07.2018

Yayın tarihi: 16.10.2018

Yazar Bilgileri

*ORCID: 0000-0002-3053-3954

Email:

muammermesci@duzce.edu.tr

\begin{abstract}
The aim of this study is to determine any potential use of Madımak plant as an herbal tea to the consumers Within the scope of this aim, Madımak herb tea was tasted to 390 participants who resided in Düzce province and after this the results were examined. In the study, in the context of quantitative research methods, survey data from 390 people were obtained. Then data were analyzed using regression analysis and descriptive statistics. Madımak plant has been determined that participants intend to purchase this tea. However, participants agreed that addition of several substances to suppress the smell of this plant would be useful. In conclusion, it has emerged that a large group of participants may consume the Madimak plant as an herbal tea.
\end{abstract}

Keywords: Madımak, Madımak Herbal Tea, Duzce City of Duzce.

\section{ÖZET}

$\mathrm{Bu}$ çalışmanın amacı, Madımak bitkisinin bitki çayı olarak tüketicinin beğenisine sunmaktır. Bu amaç kapsamında Düzce ilinde ikamet eden 390 katılımcıya Madımak bitki çayının denemesi ve sonrasında ortaya çıkan sonuç incelenmiştir. Araştırmada nicel araştırma yöntemi bağlamında 390 kişiden anket aracılığı ile veriler elde edilmiştir. Elde edilen veriler regresyon analizi ve betimleyici istatistik testlerden yararlanılarak analiz edilmiştir. Çalışma sonucunda, tüketicilerin madımak bitkisini satın almaya niyetli oldukları belirlenmiştir. Bununla birlikte katılımcılar, bu bitkinin kokusu için bir takım maddeler eklenmesinin Madımak kokusunu bastırması açısından faydalı olacağını belirtmişlerdir. Çalışma sonucunda, katılımcıların büyük çoğunun Madımak bitkisini çay olarak kullanabileceği ortaya çıkmıştır.

Anahtar Kelimeler: Madımak, Madımak Bitki Çayı, Düzce

JEL CODE: M30, M31

\footnotetext{
${ }^{1}$ This study was supported by Düzce University Scientific Research Project BAP-2016.15.01.453.

2 The Abstract of this study was presented at the Congress on International Economic and Administrative Perspectives (CIEP): New Regional Visions
} 


\section{INTRODUCTION}

In the beverage market, there are no products related to "Madımak tea". In addition, limited research has been made on this plant. With this study, it has been possible to offer the Madımak plant as a product to customers. Regarding the Madımak plant positive feedback has been provided from customers.

"Madımak plant is an edible perennial herbaceous plant that (Polygonum Cognatum), belongs to the (Polygonaceae) family with a prostrate thick woody body, and little pink flowers. The plant's distinction from species of the genus is its relatively large leaves. The plant contains essential oils, tannins, starch and glucose" (http://www.sifalibitkileriniz.com, Date of access: 28.02.2016). The benefits of Madımak can be listed as follows: "It has diuretic and a urine-enhancing feature. It is also reported to lower blood sugar. There are few studies on Madımak plant in the literature. However, it is observed that there have been studies concerning the contents of this plant. For example, Sayll (et al., 2013), compared the demographic characteristics of the participants consuming Madımak plant and investigated whether there are any differences. In a study including 245 families in the province of Tokat, it was found that consumption rate of Madımak changes in relation with being a housewife, professional, employee or being married. Önen (et al., 2014) studied the effect of moisture content of Madımak (Polygonum Cognatum Meissn.) seed to its physical characteristics (size, geometric mean diameter, surface area, sphericity, thousand grain weight, grain size, bulk and single grain bulk density, porosity, angle of repose and friction coefficient). As a result, static friction coefficient is observed to increase with increasing moisture content for various surface types (plywood, glass, fiberboard, and galvanized metal). Polygonum cognatum seeds can be easily separated in high moisture content as they are very small in size, so it was found that this could help in the increase of cultivation and germination rates of these small seeds. Demir (H., 2006), investigated Madımak (Polygonum Cognatum Maissn), salsify (Tragopogon Reticulatus Boiss.) and barberry (Berberis vulgaris L.) plants which were collected from the field in Erzurum province by examining their dry matter, ash content, $\mathrm{pH}$, ascorbic acid and mineral contents (sodium, potassium, calcium, magnesium, phosphorus, iron, copper, zinc and manganese). Alan and Padem (1989), carried out a study on Madımak which grows in Erzurum and its regions in order to demonstrate its importance in terms of healthcare and nutrition. As a result of the study, they found that Madımak has a relatively high contribution in water when it is in dry form and high levels of contribution in terms of dry matter, protein, ash and nitrogen when it is in fresh form. In studies shown above, the focus is mostly on the benefits and consumption of Madımak. A study regarding the use of Madımak as tea could not be found in local or worldwide literature. This shows the importance of our work. The introduction of this plant to literature as Madımak herbal tea shows the original nature of the work.

The aim of this study is to examine the effect of the Madımak plants as natural tea on the consumption of the customer. In addition, it is possible that these studies can be carried out for the purpose of transforming this plant into a commercial product and making this product available to the consumer market. 


\section{Herbal Teas and Benefits}

Herbal teas consumed frequently as an alternative hot drink to black tea as well as have an positive impacts on health (Sezik, 2011). The various vitamins contained in the plants used in tea production, together with the understanding of their role in preventing or treating various diseases has led to a dramatic increase in interest in herbal teas in recent years (Ivanova vd., 2005). Below is a list of some selected herbal teas and their benefits;

\section{Cranberry Tea}

Cornelian tree grows in many parts of Anatolia, especially in the Black Sea Region. Although it blooms early in February and March, it is a late fruit tree. The fruits, leaves and roots of the cornelian plant have many useful features. The cornelian tea is good for diseases such as colds, anemia, immune system (WEB-1).

\section{Linden Tea}

Linden, is grown in almost every region of Turkey. Lime flowers are collected from May to August. Benefits of linden tea are known to be good for enteric and infectious diseases, coughing, migraines and headache due to sinusitis as well as diseases such as liver disorders and vascular stiffness (WEB-2).

\section{Chamomile Tea}

Chamomile is a plant that blooms in yellow and white colors, spontaneously growing on road sides, empty fields and various fields. It is also made from chamomile tea. Papates are collected without stem and dried in the shade. The benefits of chamomile tea are lowering fever, relieving aches, resolving spasms, helping to sweat. It relieves nerves, removes intestinal gas, comforts the body, removes inflammation of the throat and gingiva, passes the waist and headache (WEB-3)

\section{Green Tea}

Green tea is obtained from the same plant as black tea. The difference between the two is that the black teapot is less processed. Green tea is regarded as the homeland of China. Green tea protects your heart health, regulates blood pressure, increases immunity (WEB$6)$.

\section{Rosehip Tea}

Rosehips bloom in summer and the berry reaches full maturity in the last spring. In terms of physical structure and precipitation, the Black Sea region is considered to be the homeland of the rosehip plant. Rosehip tea is rich in vitamin C. This vitamin is necessary for calogenesis, which is considered an important component of skin and connective tissue. The body increases resistance to colds, flu, fever, colds. It strengthens the vein walls and helps prevent bleeding. Because antioxidant is a fruit, it causes carcinogenic effects with other vitamins in the body. Allows the use of the loins taken with food to be used (WEB4).

\section{Chia Tea}

Chia tea is prepared from the seeds of the plant. It has a natural antibiotic effect. Chia seeds are black, round shaped. Chia seeds prevent blood clotting, strengthen heart muscles, 
have positive effects on vascular health, as well as positive effects on nails, hair and skin (WEB-1)

\section{Tea Viburnum}

Viburnum opulus is a bushy tree. Usually grown in Kayseri and Central Anatolia. It is a round fruit with a red cluster. The kidney friendly Viburnum opulus opens white flowers in the spring. The fruit is collected in the autumn. Vitamin $C$ is quite rich in terms. Viburnum opulus, identified with Kayseri, is used by the people of the region to drop kidney stones. Viburnum opulus also has urine boosting, laxative and sedative effects. Biliary and liver diseases are consumed as fruit or fruit juice. It is commonly called tea viburnum and is good for kidney disorders, urinary tract disorders, heart diseases, joint and rheumatic diseases (WEB-5).

Above we have been informed about some herbal teas and the benefits of these teas. A significant number of tourists come to our country and Chinese tourists are an important part of them. Chinese tourists are known to love and consume herbal teas. In this sense, producing different herbal teas is meaningful in many ways. Therefore, it is very important to uncover the Madımak herbal tea we have discussed in article and to present it to the likes of tourists. In this way, the possibility of testing different herbal teas will be provided and the production of these herbal teas will provide important contributions to the economy.

\section{MATERIAL AND METHODS}

\section{Aim of This Study}

The aim of this study is to examine the effect of the Madımak plants as natural tea on the consumption of the customer. Within this framework, consumers which showed proof of residence in the province of Düzce were included in the study. The method of research is based on quantitative research method. In the study, the data were obtained with the help of survey technique in terms of quantitative research methods.

\section{Population and Sampling of This Study}

The population of this study are consumers living in Düzce. The population of Düzce is 360.388 (http://www.nufusu.com/il/duzce-nufusu Date of access: 19,11,2016). As this population has been achieved in Düzce City, it was examined by sampling method. Data were obtained by applying face to face survey to 390 citizens in Düzce in 2016. According to Sekaran (2003), a sample size of 384 would be enough in case of the universe being $10,000,000$ (Sekeran, U. 2003). In data collection, stratified sampling was used. In the study, a total of 390 data were obtained in the months of October and November.

\section{Normality Analysis of This Study}

At the start of the analysis, data were subjected to the distribution normality test. With this purpose, normality assumption was investigated and it was determined that skewness and kurtosis values of the analysis data set were between the desired values of $(+1.5 /-1.5)$, (Tabachnick and Fidell, 2013). In the study, as the data showed normal distribution, analysis was continued through parametric tests. Within this context, regression analysis was included in the study. 


\section{Reliability and Validity of This Study}

Reliability is the degree of measurements to remain free from error. In the literature there are methods used in relation with validity. The most commonly used method is Cronbach's alpha validity value. Cronbach's alpha internal validity value is between 0 and 1 and as the value comes closer to 1. consistency / reliability increases (Cronbach, L. J. 1990).

The survey technique was used to collect data in the study. In this context, after a literature review was conducted, a questionnaire form was created benefiting from the studies undertaken by Kucukaydin (S. 2012), on attitudes towards consumption of herbal teas. The developed questionnaire was then given the final shape by receiving opinions of two experts (an academician and an adviser). The questionnaire form consists of two main parts. In the first section, there are statements for determining the attitudes of respondents towards Madımak herbal tea and it contains a five-point Likert scale. The questionnaire form includes a total of 15 statements. Seven of these statements are about the elements participants care about when they buy herbal tea and the other eight statements are for determining the attitudes of consumers when buying Madımak herbal tea. In the second part of the questionnaire, questions are prepared to determine demographic characteristics of the participants.

After the questionnaire form was prepared, preliminary study was conducted. Preliminary study was applied to 50 participants between the dates of September 1st 2016 and September 15th, 2016. Before the questionnaire forms were applied, the participants were informed about the aim of the study and after this survey forms were distributed. After a period of time, the survey forms were collected. After the application of the forms, reliability of the data obtained from the forms were measured. Cronbach alpha value of the data obtained from the preliminary application was calculated to be 0.79 . The overall Cronbach's alpha value of the data in the test results was above the level of 0.7 specified by Nunnally (C. Jum 1967). Next, the survey form was examined by the experts on the subject again, and their opinions were asked. Later, a total of 400 questionnaires were distributed to the participants. 390 of the forms were answered. Other questionnaires could not be taken into consideration as they were not answered. In analyzing the obtained data, SPSS 18 software was used. Identifier statistics techniques, such as frequency, regression and percentage for analysis of the demographic data were utilized. 


\section{Hypotheses in the of Research}

H1: The flavor of Madımak herbal tea has a positive effect on the consumption of participants.

H2: The image of Madımak herbal tea has a positive effect on the consumption of participants.

H3: The smell of Madımak herbal tea has a positive effect on the consumption of participants.

\section{Results and Discussion}

The number of surveys which were answered is 390. Considering the return rates, return rate for the questionnaires amounted to \%98. The results related to demographic findings of the analysis of the carried-out survey forms are shown below. By applying frequency and percentage analysis on the data, demographic findings of the surveyed participants were reached. Of the participants, 238 are men and 152 of them are female. In this case, the ratio of men to women is $61.0 \%$, while the ratio of women to men is $39.0 \%$. It was determined that 184 of participants are married; 199 of them are single and 7 of them are neither married nor single. When age groups of participants are analyzed; 49 participants (12.6\%) are in the 15-20 age range; 105 participants (26.9\%) are in the 21-25 age range; 57 participants (14.6\%) are in the 26-30 age range; 39 participants (10.0\%) are in the $31-35$ age range; 39 participants (10.0\%) are in the 36-40 age range; 41 participants $(10.5 \%)$ are in the 41-45 age range and finally, 60 participants (15.4\%) are in the range of 45 years age and older. 
Table 1. The Result of Demographic Findings of the Analysis ( $\mathrm{n}=390)$

\begin{tabular}{|c|c|c|c|}
\hline & & $\mathrm{F}$ & $\%$ \\
\hline \multirow{3}{*}{ Gender } & Female & 152 & 39,0 \\
\hline & Male & 238 & 61,0 \\
\hline & Total & 390 & 100 \\
\hline \multirow{8}{*}{ Age } & $15-20$ & 49 & 12,6 \\
\hline & $21-25$ & 105 & 26,9 \\
\hline & $26-30$ & 57 & 14,6 \\
\hline & $31-35$ & 39 & 10,0 \\
\hline & $36-40$ & 39 & 10,0 \\
\hline & $41-45$ & 41 & 10,5 \\
\hline & 45 and over & 60 & 15,4 \\
\hline & Total & 390 & 100 \\
\hline \multirow{6}{*}{$\begin{array}{c}\text { Education } \\
\text { Status }\end{array}$} & Primary Education & 56 & 14,4 \\
\hline & High School & 87 & 22,3 \\
\hline & License & 73 & 18,7 \\
\hline & Graduate & 150 & 38,5 \\
\hline & Graduate/Post Graduate & 24 & 6,1 \\
\hline & Total & 390 & 100 \\
\hline \multirow{6}{*}{ Income } & $500 €$ and less & 110 & 28,2 \\
\hline & 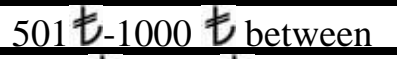 & 50 & 12,8 \\
\hline & $1001 €$-2000 $€$ between & 112 & 28,7 \\
\hline & 2001も-3000 $€$ between & 67 & 17,2 \\
\hline & $3000 €$ and over & 49 & $\overline{12,6}$ \\
\hline & Toplam & 388 & 95,5 \\
\hline \multirow{4}{*}{ Marital Status } & Evli & 184 & 47,2 \\
\hline & Bekâr & 199 & 51,0 \\
\hline & Diğer & 7 & 1,8 \\
\hline & Toplam & 390 & 100 \\
\hline \multirow{8}{*}{ Your Job } & Public Employee & 75 & 19,2 \\
\hline & Retired & 27 & 6,9 \\
\hline & Private Sector & 71 & 18,2 \\
\hline & Student & 146 & 37,4 \\
\hline & Housewife & 39 & 10,0 \\
\hline & Unemployed & 13 & 3,3 \\
\hline & Other & 18 & 4,6 \\
\hline & Total & 389 & 99,7 \\
\hline
\end{tabular}

When the education level of participants who completed the questionnaire were analyzed, we see that 56 participants $(14,4 \%)$ are primary school graduates; 87 participants $(22,3 \%)$ are high school graduate; 73 participants $(18,7 \%)$ have associate's degree; 150 participants $(38,5 \%)$ have under-graduate degree; and 24 participants $(6,1 \%)$ have a graduate degree.

When the income level of the participants were examined, it is determined that 110 participants $(28,2 \%)$ have an income below $€ 500 ; 50$ participants $(12,8 \%)$ have an income between $€ 501$ and $€$ 1,000; 112 participants $(28,7 \%)$ have an income between 
1001 and $€$ 2000; 67 participants $(17,2 \%)$ have an income between $も 2001$ and $も$ 3000 and 49 participants have an income of $€ 3000$ and higher.

When the employment status of participants was examined, it is seen that 75 participants $(19,2 \%)$ are public employees; 27 participants $(6,9 \%)$ are retired; 71 participants $(18,2 \%)$ are in the private sector; 146 participants $(37,4 \%)$ are students; 39 participants $(10,0 \%)$ are housewives; 13 participants $(3,3 \%)$ are unemployed, and finally 18 participants $(4,6 \%)$ were determined to belong to other occupational groups.

\section{Descriptive Analysis Results}

When we examine the answers based on participants' purchasing the herbal tea, the highest average statement, emerges to be "I look to the quality" (Avg.=4.36) This statement is followed by "I prefer it to be a known Brand" (Avg.=4.10) This statement is followed by "The price is important to me." (Avg.=3.00) And this statement is followed by "I do not pay attention to design" (Avg.=2.93)" Finally, the statement with the lowest average on participants' purchasing the herbal tea is "where it is produced is not important" (Avg.=2.65) On the other hand, the participants were asked how often they consume herbal tea. Hence, the number of participants often using the herbal tea is $56(\% 14,3)$; the number of participants occasionally using herbal tea is $182(\% 46,7)$; the number of participants rarely using herbal tea is $110(\% 28,2)$, and the number of participants who never use herbal tea is found to be 42(\%10,8) (Avg.=2.35). Another question that was asked to the participants was "what brands do you prefer as herbal tea? "The answers to the question varied as follows: the number of participants consuming $X$ brand is 65 ; the number of participants consuming $\mathrm{Z}$ brand is 168 ; the number of participants consuming $\mathrm{Y}$ brand is 103 and and the number of participants consuming other brands of herbal tea is 54 (Avg. $=2.37$ )

When the results on use of the Madımak herbal tea were examined the highest average belongs to the "I like the its flavor" statement (Avg.=3.70). This phrase is followed by "I love its smell" statement (Avg.=3.34) This is followed by "I liked its image" (Avg.=3.32). Finally, the lowest average belongs to the "I'd like to use this herbal tea" statement (Avg.=3.14)

When the absolute intention of participants on buying the Madımak herbal tea is examined, the results of analysis show that $147(\% 37,7)$ participants intend to purchase the tea and 55 $(\% 14,1)$ participants absolutely intend to purchase the tea. When the analysis on participants' absolute buying the Madimak herbal tea is examined, it is found that 150 $(\% 38,5)$ participants want to purchase the tea and $53(\% 13,6)$ participants absolutely want to purchase the tea. In addition, when the analysis on participants' probably purchasing the Madımak herbal tea is examined, it is determined that $144(\% 36,9)$ participants want to purchase the tea and $55(\% 14,1)$ participants probably want to purchase the tea. On the other hand, when the analysis concerning participants' not purchasing the Madimak herbal tea is examined, it is seen that $69(\% 17,7)$ participants stated that they don't want to purchase the tea and $29(\% 7,4)$ participants stated that they will never purchase the tea. 


\section{Findings Related to Regression Analysis}

Prior to the analysis, initially, normality assumption was researched in the study it was found that data showed normal distribution.

Table 2: Regression results regarding the flavor of Madımak effect on the consumption of participants

\begin{tabular}{|c|c|c|c|c|c|c|c|}
\hline \multirow[t]{2}{*}{ Model } & \multicolumn{2}{|c|}{$\begin{array}{c}\text { Unstandardized } \\
\text { Coefficients }\end{array}$} & \multirow{2}{*}{$\begin{array}{c}\text { Standardized } \\
\text { Coefficients } \\
\text { Beta }\end{array}$} & \multirow{2}{*}{$\mathrm{t}$} & \multirow{2}{*}{ Sig. } & \multicolumn{2}{|c|}{ Collinearity Statistics } \\
\hline & B & $\begin{array}{l}\text { Std. } \\
\text { Error }\end{array}$ & & & & Tolerance & VIF \\
\hline (Constant) & ,987 &, 145 & & 6,790 & ,000 & & \\
\hline $\begin{array}{c}\text { Madımak } \\
\text { flavor }\end{array}$ & ,637 &, 037 & ,654 & 17,008 & ,000 & 1,000 & 1,000 \\
\hline
\end{tabular}

According to the result of regression in Table 2, the significance value of $\mathrm{p}<, 0,05$ shows that the model is significant. $F(1388)=289.288$. Beta $(\beta)$ coefficients indicate how much independent variables are effective on the dependent variables. When standardized $\beta$ coefficients in the table above are examined, the taste of the Madimak plant is seen to affect the consumption of participants to the level of $\beta=0,65$. In other words, one unit increase in the independent variable (predictors) reveals a change on dependent variable (predicted) in the amount of 0.65 level. When $t$ values are examined( $t=17,008)$, the flavor of the Madimak plant is seen to have a significant effect on absolute consumption (predictor) of participants (Büyüköztürk, S. 2008). In the context of these results, it is determined that the flavor of the Madımak plant has a positive effect on absolute consumption of participants. In this context, the hypothesis H1 was accepted.

Table 3: Regression results regarding the image of Madımak effect on the consumption of participants

\begin{tabular}{|c|c|c|c|c|c|c|c|}
\hline \multirow{2}{*}{ Model } & \multicolumn{2}{|c|}{$\begin{array}{c}\text { Unstandardized } \\
\text { Coefficients }\end{array}$} & $\begin{array}{c}\text { Standardized } \\
\text { Coefficients }\end{array}$ & \multirow{2}{*}{$\mathrm{t}$} & \multirow{2}{*}{ Sig. } & \multicolumn{2}{|c|}{ Collinearity Statistics } \\
\cline { 2 - 3 } \cline { 7 - 8 } & $\mathrm{B}$ & Std. Error & Beta & & & Tolerance & VIF \\
\hline $\begin{array}{c}\text { (Constant) } \\
\text { Image of } \\
\text { Madımak }\end{array}$ & 1,548 &, 191 & & 8,094 &, 000 & & \\
&, 466 &, 048 &, 444 & 9,750 &, 000 & 1,000 & 1,000 \\
\hline
\end{tabular}

According to the result of regression in Table 3, the significance value of $p<0,05$ shows that the model is significant. F (1.388) $=95.055$. When standardized $\beta$ coefficients in the table above are examined, the image of the Madımak plant is seen to affect the consumption of participants to the level of $\beta=$,44.In other words, one unit increase in the independent variable (predictors) reveals a change on dependent variable (predicted) in the amount of 0.44 . When $t$ values are examined $(t=9,750)$ the image of the Madimak plant is seen to have a significant effect on absolute consumption (predictor) of participants (Büyüköztürk, S. 2008). In this context, it is observed that the image of Madımak herbal 
tea has a positive effect on absolute consumption of participants. In this context, the hypothesis $\mathrm{H} 2$ was accepted.

Table 4: Regression results regarding the smell of Madımak effect on the consumption of participants

\begin{tabular}{|c|c|c|c|c|c|c|c|}
\hline \multirow{2}{*}{ Model } & \multicolumn{2}{|c|}{$\begin{array}{c}\text { Unstandardized } \\
\text { Coefficients }\end{array}$} & $\begin{array}{c}\text { Standardized } \\
\text { Coefficients }\end{array}$ & \multirow{2}{*}{$\mathrm{t}$} & \multirow{2}{*}{ Sig. } & \multicolumn{2}{|c|}{$\begin{array}{c}\text { Collinearity } \\
\text { Statistics }\end{array}$} \\
\cline { 2 - 4 } & $\mathrm{B}$ & Std. Error & Beta & & & Tolerance & VIF \\
\hline $\begin{array}{c}\text { 1(Constant) } \\
\begin{array}{c}\text { Smell of } \\
\text { Madimak }\end{array}\end{array}$ & 1,422 &, 135 & & 10,570 &, 000 & & \\
&, 548 &, 036 &, 611 & 15,198 &, 000 & 1,000 & 1,000 \\
\hline
\end{tabular}

According to the result of regression in Table 4, the significance value of $\mathrm{p}<0,05$ shows that the model is significant. F (1.388) $=230.972$. When standardized $\beta$ coefficients in the table above are examined, the smell of Madımak plant is seen to affect the consumption of participants to the level of $\beta=, 61$. When $t$ values are examined $(t=15,198)$, the smell of Madımak herbal tea is seen to have a significant effect on absolute consumption (predictor) of participants (Büyüköztürk, S. 2008). According to this result, it can be said that the smell of Madımak herbal tea has a positive effect on absolute consumption of participants. In this context, the hypothesis $\mathrm{H} 3$ was accepted.

\section{CONCLUSION AND EVALUATION}

In this study, the aim of this study is to examine the effect of the Madimak plants as natural tea on the consumption of the customer. Considering the data obtained from participants it can be assumed that Madimak plant can be used as "tea" and this plant can also be turned into a commercial product available to the consumer market with the help of necessary research. Participants are requested their opinion on the Madımak plant. In this context, it is found that participants generally enjoy this herbal tea, can consume it as herbal tea, and even they have a tendency to purchase.

All the hypotheses put forward in the study were accepted. Among the hypotheses, specifically, it has been determined that consuming the Madımak herbal tea has $71 \%$ positive effect on absolute consumption of participants.

However, overall suggestion of participants regarding the plant is the need for further efforts be made for the smell of the plant. On the other hand, they expressed that they liked the flavor of this plant. In fact, some participants expressed that even though they don't consume herbal teas, they liked Madımak herbal tea. In the future, similar studies can be carried out in different regions in a quantitative research context. Additionally, further research can be done for turning this plant into a commercial product and put this new product on the market. 


\section{REFERENCES}

Alan, R. ve Padem, H. (1989). Erzurum ve yöresinde sebze olarak kullanılan, evelik kızılca, kuşekmeği, deliçaşır ve yemlik otlarının besin değeri üzerine bir araştırma, The Journal of Food, 14 (5), ss.281-287.

Büyüköztürk, Ş. (2008). Veri Analizi El Kitabı, 9 nd ed, Ankara: Pegem Yayıncılık,

Cronbach, L. J. (1990). Essentials of Psychological Testing, New York: Harper \& Row.

Demir, H. (2006). Erzurum'da yetişen Madımak, yemlik ve kızamık bitkilerinin bazı kimyasal bileşimi. Bahçe, 35(1-2), ss.55-60.

Ivanova D, Gerova D, Chervenkov T, Yankova T. (2005). Polyphenols and Antioxidant Capasitiy of Bulgarian Medicinal Plants. J Ethnopharmacol, 96: 145-150.

Kucukaydın, S. (2012). Tüketici Etnosentrizmi ve Ülke Menşei Etkisinin Tüketicilerin Yabancı Markalı Ürün Tercihi Ve Satın Alma Niyeti Üzerine Etkisi, Basılmamış Doktora Tezi, Marmara Üniversitesi, Sosyal Bilimler Enstitüsü, İstanbul

Nunnally C. Jum (1967). Psychometric Theory, New York: MacGraw-Hill,

Önen, H., Altuntaş, E., Özgöz, E., Bayram, M. And Özcan, S. (2014). Moisture effect on physical properties of Knotweed (Polygonum Cognatum Meissn), Journal of Agricultural Faculty of Gaziosmanpasa University, 31 (2), 15-24.

Sayıl1, M., Adiguzel, F. and Gozener, B. (2013). Investigation on Madımak consumption status of consumers in central Tokat province. Bulgarian journal of agricultural science, 19(2), ss.303-313.

Sekeran, U. (2003). Research methods for business: A skill building approach, 4th Edition, New York: John Wiley,

Sezik E. (2011). Bitkilerin Dünyası: Dostlar. Klinik Toksikoloji Derneği 16. Kongresi, 1821 Mayıs, Kayseri, Türkiye, 28.

Tabachnick, B. G. ve Fidell, L. S. (2013). Using multivariate statistics, Boston: Pearson.

WEB-1, http://www.faydalicaylar.com, Erişim Tarihi: 09.07.2018.

WEB-2, www.medikalakademi.com.tr, Erişim Tarihi: 09.07.2018.

WEB-3, www.sabah.com.tr, Erişim Tarihi: 09.07.2018.

WEB-4, www.kusburnu.gen.tr, Erişim Tarihi: 09.07.2018.

WEB-5, http://www.gilaburu.com.tr, Erişim Tarihi: 09.07.2018.

WEB-6, https://www.cayic.com/yesil-cayin-faydalari Erişim Tarihi: 09.07.2018.

http://www.1organik.com, Date of access:28.02.2016).

http://www.nufusu.com/il/duzce-nufusu Date of access: 19.11.2016).

http://www.sifalibitkileriniz.com, Date of access:28.02.2016). 


\section{AUTOBIOGRAPHY}

Assoc. Dr.Muammer Mesci completed his master's degree in tourism and hotel management at Düzce University and completed his doctorate in Business Administration at Sakarya University Institute of Social Sciences. Dr. Mesci's academic interests include; performance management, innovation management and tourism management.

\section{ÖZGEÇMİ̧̧}

Doç. Dr. Muammer MESCİ, Düzce Üniversitesinde Akçakoca Turizm İşletmeciliği ve Otelcilik Yüksekokulunda lisansını tamamlamıştır. Düzce Üniversitesinde Turizm ve Otel İşletmeciliği alanında yüksek lisans yaptıktan sonra Sakarya Üniversitesi Sosyal Bilimler Enstitüsü İşletme Ana Bilim Dalı'nda doktorasını tamamlamıştır. Dr. Mesci’nin akademik ilgi alanları; performans yönetimi, yenilik yönetimi ve turizm işletmeciliğidir. 